\title{
Ethylene-forming Bacteria from Soil and Water
}

\author{
By S. B. PRIM ROSE \\ Department of Biological Sciences, University of Warwick, Coventry $\mathrm{CV}_{4}{ }_{7} A L$
}

(Received 28 June 1976)

\section{INTRODUCTION}

The biological production of the plant hormone ethylene is not limited to higher plants. Biale (I940) and Miller, Winston \& Fisher (1940) independently discovered that the common green mould on citrus fruits, Penicillium digitatum, produces ethylene at a high rate. Subsequent studies (Nickerson, 1948; Ilag \& Curtis, 1968; Chalutz \& Devay, 1969; Lynch, 1972) have shown ethylene production by fungi and by the bacteria Pseudomonas solanacearum (Freebairn \& Buddenhagen, I964), Escherichia coli, Pseudomonas sp. and an unidentified soil isolate (Primrose \& Dilworth, 1976; Primrose, 1976).

Kramer (195I) suggested that ethylene from the soil might be involved in waterlogging damage, since flooding and ethylene can have similar effects on plants. Later Smith \& Russell (1969) showed that soils incubated at field capacity liberated significant quantities of ethylene. Since the production of ethylene was halved after the soil had been sterilized by ionizing radiation and almost eliminated by heating (Smith \& Restall, 197I), ethylene might be produced either by micro-organisms or by free enzyme activity. By amending soil with ethylene precursors, Lynch (1972) was able to isolate Mucor hiemalis, Candida vartiovaariai and Trichosporon cutaneum, which produced ethylene in pure culture. Smith \& Cook (1974) suggested that anaerobic spore-forming bacteria formed ethylene in the soil but did not attempt to isolate these organisms. Since then, a number of ethylene-producing bacteria have been isolated from waterlogged soil (Primrose \& Dilworth, 1976) and this investigation was undertaken to determine their occurrence in soil and water.

\section{METHODS}

Sixty-one soil and water samples were collected in sterile $25 \mathrm{ml}$ vials with the aid of sterile spatulas or pipettes. Water samples were collected from a variety of habitats, for example mountain streams, drainage ditches, ponds and lakes. Soil samples were collected from different parts of the country so that different types, for example sandy loam, clay, peat, were obtained.

Samples of soil and water were inoculated in $20 \mathrm{ml}$ defined liquid medium (Brown \& Dilworth, 1975) supplemented with glucose $(0.4 \%, \mathrm{w} / \mathrm{v})$ and methionine $\left(500 \mu \mathrm{g} \mathrm{ml}^{-1}\right)$ in $250 \mathrm{ml}$ conical flasks which were sealed with alcohol-sterilized rubber serum caps (Suba-Seal; Wm Freeman, Barnsley, Yorkshire). Flasks were incubated in the dark at $30^{\circ} \mathrm{C}$. Gas samples ( $\mathrm{I} \mathrm{ml}$ ) were withdrawn through the rubber seals and analysed by gas-liquid chromatography using a flame ionization detector and a $\mathrm{I} \cdot 5 \mathrm{~m} \times 5 \mathrm{~mm}$ column of Porapak $R$ operated isothermally at $85^{\circ} \mathrm{C}$. Soil and water cultures showing ethylene production were diluted in nutrient broth and samples of each dilution were spread on nutrient agar plates which were incubated at $30^{\circ} \mathrm{C}$ for 5 days. The different types of bacteria, as judged by colonial morphology, were purified by restreaking on nutrient agar and then tested for ethylene production as described above. 
Ethylene-producing isolates were tentatively identified on the basis of the following tests: shape, spore formation, Gram reaction, pigmentation, motility, anaerobic growth, fermentation of glucose in the Hugh and Leifson test, and catalase and oxidase activities. All tests were carried out as described by Cowan \& Steel (1973). Gram-negative fermentative isolates were further classified by means of API $20 \mathrm{E}$ diagnostic kits (API Laboratory Products, Rayleigh, Essex).

Cell-free filtrates were produced by centrifuging cultures and passing the supernatant fluid through a $0.22 \mu \mathrm{m}$ filter.

Quantitative catalase assays were performed as described by Herbert (1955).

\section{RESULTS AND DISCUSSION}

All inoculated broths released at least I 50 nmol ethylene within 3 days at $30^{\circ} \mathrm{C}$ and many produced considerably more. From these broths, 756 pure isolates were obtained but 259 failed to grow in the defined medium and were discarded. Of the remainder, 79 produced more than $40 \mathrm{nmol}$ ethylene in 3 days and were retained. These were all Gram-negative bacteria. By using medium containing polymyxin $\mathrm{B}\left(5 \mu \mathrm{g} \mathrm{ml}^{-1}\right)$, to supress the growth of Gram-negative bacteria, six Gram-positive isolates which produced ethylene were obtained.

Proportions of ethylene-producing bacteria in several freshly collected samples of soil and water were estimated by testing isolates from dilution plates prepared with nutrient agar. Eleven out of $112(9.8 \%), 11 / 53(20.7 \%), 4 / 40(10 \%)$ and $7 / 117(6 \%)$ isolates from four soil samples produced more than $30 \mathrm{nmol}$ ethylene within 3 days. Similarly, $7 / 60$ (I I $7 \%$ ), 9/50 $(18 \%), 3 / 67(4.5 \%)$ and $6 / 39(15.4 \%)$ isolates from four water samples produced ethylene. Since many isolates failed to grow in the defined medium used to test for ethylene production, the numbers of ethylene-producing organisms could be higher. Unfortunately, we have no way of knowing how many of these isolates produce ethylene in their natural habitat. Furthermore, since no single medium has been devised which will support the growth of all the bacteria present in soil or water it is impossible to assess the proportion of the total microbial population which is being examined.

Sixty-five of the Gram-negative ethylene-producing isolates were identified (Table I). Of the 49 fermentative isolates, I 2 were classified as Aeromonas hydrophila and the other 37 as enterics. The 16 non-fermentative Gram-negative isolates were identified as Pseudomonas sp., four belonging to group II and two to group III or IV of Shewan, Hobbs \& Hodgkiss (I960); the others are probably Pseudomonas indigofera (Elazari-Volcani, I939; McFadden \& Howes 1961). Five of the putative $P$. indigofera isolates form characteristic blue colonies which leave a blue print after removal of the bacteria from the agar and are unusual in producing indole. The other isolates identified as $P$. indigofera did not produce the blue pigment but were biochemically identical with the pigmented isolates. Of the Gram-positive isolates, two were identified as Arthrobacter sp. and the remainder resembled Arthrobacter but were too saccharolytic to be classified in the genus.

All the isolates obtained produced ethylene only when methionine was present in the growth medium, suggesting that it is the precursor for ethylene. These isolates thus resemble M. hiemalis, C. vartiovaariai and T. cutaneum (Lynch, 1972) and plant tissues (Yang, 1974). Only Penicillium digitatum appears to use a substrate other than methionine for ethylene production (Chou \& Yang, 1973). The ability to produce ethylene from methionine does not appear to be related to the organisms' ability to use methionine as a sole source of nitrogen or sulphur. Approximately $50 \%$ of the enteric isolates were unable to use methionine as a sole sulphur source and approximately $40 \%$ were unable to use it as a sole nitrogen source. 
Table I. Identity of ethylene-producing bacteria

Organism
Citrobacter sp.
Enterobacter cloacae
Erwinia herbicola
Escherichia coli
Klebsiella pneumoniae
K. pneumoniae oxytoca
K. ozaenae
Serratia liquefaciens
Aeromonas hydrophila
Pseudomonas group Ir
Pseudomonas group III or IV
P. indigofera
Arthrobacter sp.
Saccharolytic coryneforms

No. of isolates

2

4

9

I3

I

I

1

I 2

4

2

IO

2

4
Ethylene produced in $66 \mathrm{~h}$ [nmol (mg dry wt) $\left.{ }^{-1}\right]$

$$
\begin{gathered}
45-82 \\
\text { III-142 } \\
41-950 \\
97-374 \\
43-546 \\
341 \\
146 \\
78 \\
40-722 \\
236-542 \\
600-1095 \\
650-6195 \\
82-800 \\
40-410
\end{gathered}
$$

Lynch (1974) and Primrose (1976) have observed that in $M$. hiemalis and E. coli respectively, cell-free filtrates of cultures grown in the presence of methionine are capable of releasing ethylene on illumination. Cell-free filtrates from all the ethylene-producing isolates described here also produced ethylene in the presence of light, supporting the view that methionine is metabolized to an intermediate which is converted to ethylene either enzymically or photochemically (Lynch, 1974; Primrose, 1976).

All the ethylene-producing bacteria isolated in this study grew aerobically and produced ethylene only in the presence of oxygen. This observation conflicts with the concept of an ethylene-oxygen cycle as proposed by Smith \& Cook (1974). They suggested that anaerobic microsites are continually formed in soil as a result of the activities of aerobic microbes and that ethylene is produced by anaerobic spore-forming bacteria in such microsites. The ethylene would then diffuse through the soil and inhibit the aerobic microbes resulting in an increase in oxygen tension and cessation of ethylene production. Lynch (1975) has shown that many fungi are unaffected by ethylene and none of our isolates was inhibited by

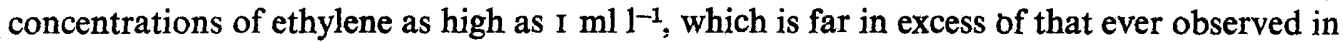
soils.

A significant proportion ( $12 \%$ ) of the Gram-negative ethylene-producing isolates had barely detectable catalase activity and there was a good correlation between the catalase activity of a culture and its ability to produce ethylene. For example, eight of the best ethylene producers [ 1095 to $6112 \mathrm{nmol}(\mathrm{mg} \text { protein })^{-1}$ ] had catalase activities of 0.32 to 9. I $\mathrm{ml} \mathrm{g}^{-1} \mathrm{~s}^{-1}$, whereas the five poorest producers [40 to III nmol (mg protein) ${ }^{-1}$ ] had catalase activities of 176 to $631 \mathrm{ml} \mathrm{g}^{-1} \mathrm{~s}^{-1}$. The poor catalase activities of the best producers may be relevant to the mechanism of ethylene biogenesis. Yang (1967) has shown that peroxidase can generate ethylene from methionine derivatives and catalase is known to be an inhibitor of peroxidase activity.

Several of the isolates secreted yellow water-soluble pigments with the spectral properties of flavins. On illumination, cell-free filtrates from such cultures released ethylene much more rapidly than filtrates from cultures not secreting such pigments. Evidence for a role for these pigments in ethylene formation is strengthened by the observations of Yang, $\mathrm{Ku} \&$ Pratt (I967) and $\mathrm{Ku} \&$ Leopold (1970) that the photochemical production of ethylene from methionine and its derivatives is mediated by flavins, particularly at low $\mathrm{pH}$ values. 
The author thanks Miss Margaret Hendrie, Torry Research Station, Aberdeen, for identifying all non-fermentative Gram-negative isolates, Dr Dorothy Jones, University of Leicester, for identifying all Gram-positive isolates, and D. Hodgson for assistance with catalase assays.

\section{REFERENCES}

BIALE, J. B. (1940). Effect of emanations from several species of fungi on respiration and colour development of citrus fruits. Science $9 \mathrm{r}, 458-459$.

Brown, C. M. \& Dilworth, M. J. (1975). Ammonia assimilation by Rhizobium cultures and bacteroids. Journal of General Microbiology 86, 39-48.

Chalutz, E. \& Devay, J. E. (1969). Production of ethylene in vitro and in vivo by Ceratocystis fimbriata in relation to disease development. Phytopathology 59, 750-755.

Chou, T. W. \& YANG, S. F. (1973). The biogenesis of ethylene in Penicillium digitatum. Archives of Biochemistry and Biophysics 157, 73-82.

COWAN, S. T. \& STEEL, K. J. (1973). Manual for the Identification of Medical Bacteria, 2nd edn. Cambridge: Cambridge University Press.

Elazari-Volcani, B. (1939). On Pseudomonas indigofera (Voges) Migula and its pigment. Archiv für Mikrobiologie 10, 343-358.

FreebaIRN, H. T. \& BUDDENHAGEN, I. W. (1964). Ethylene production by Pseudomonas solanacearum. Nature, London 202, 313-3I4.

HERBERT, D. (1955). Catalase from bacteria (Micrococcus lysodeikticus). Methods in Enzymology 2, 784-788.

IlaG, L. \& CurTis, R. W. (1968). Production of ethylene by fungi. Science 159, 1357-1358.

Kramer, P. J. (195I). Causes of injury to plants resulting from flooding of the soil. Plant Physiology 26, $722-736$.

KU, M.S. \& Leopold, A. C. (1970). Ethylene formation from peptides of methionine. Biochemical and Biophysical Research Communications 41, $1155-1160$.

LYNCH, J. M. (1972). Identification of substrates and isolation of micro-organisms responsible for ethylene production in the soil. Nature, London 240, 45-46.

LYNCH, J. M. (1974). Mode of ethylene formation by Mucor hiemalis. Journal of General Microbiology 83 , 407-411.

LYNCH, J. M. (1975). Ethylene in soil. Nature, London 256, 516-517.

McFadden, B. A. \& Howes, W. V. (196I). Pseudomonas indigofera. Journal of Bacteriology 8r, 858-862.

Miller, E. V., Winston, J. R. \& Fisher, D. F. (I940). Production of epinasty by emanations from normal and decaying citrus fruits and from Penicillium digitatum. Journal of Agricultural Research 60, 269-277.

NICKERSON, W. J. (1948)! Ethylene as a metabolic product'of the pathogenic fungus Blastomyces dermatitidis. Archives of Biochemistry and Biophysics 17, 225-233.

Primrose, S. B. (1976). Formation of ethylene by Escherichia coli. Journal of General Microbiology 95, 159-165.

Primrose, S. B. \& Dilworth, M. J. (1976). Ethylene production by bacteria. Journal of General Microbiology 93, 177-18I.

ShewaN, J. M., HobBs, G. \& Hodgkiss, W. (1960). A determinative scheme for the identification of certain genera of Gram-negative bacteria, with special reference to the Pseudomonadaceae. Journal of Applied Bacteriology 23, 379-390.

SMITH, A. M. \& CoOK, R. J. (1974). Implications of ethylene production by bacteria for biological balance of soil. Nature, London 252, 703-705.

SMITH, K. A. \& Restall, S. W. F. (197I). The occurrence of ethylene in anaerobic soil. Journal of Soil Science 22, 430-443.

SMTtH, K. A. \& RuSSELL, R. S. (1969). Occurrence of ethylene and its significance in anaerobic soil. Nature, London 222, 769-771.

YANG, S. F. (1967). Biosynthesis of ethylene: ethylene formation from methional by horseradish peroxidase. Archives of Biochemistry and Biophysics r22, 481-487.

YANG, S. F. (1974). The biochemistry of ethylene: biogenesis and metabolism. In The Chemistry and Biochemistry of Plant Hormones, pp. 13I-164. Edited by V. C. Runeckles, E. Sondheimer and D. C. Walton. New York: Academic Press.

YANG, S. F., KU, M. S. \& PRATT, H. K. (1967). Photochemical production of ethylene from methionine and its analogues in the presence of flavin mononucleotide. Journal of Biological Chemistry 242, 5274-5280. 